\title{
Use of Mangroves by Lemurs
}

\author{
Charlie J. Gardner ${ }^{1,2}$
}

Received: 16 January 2016 / Accepted: 20 April 2016 / Published online: 14 May 2016

(C) The Author(s) 2016. This article is published with open access at Springerlink.com

\begin{abstract}
Despite an increasing recognition of the ecosystem services provided by mangroves, we know little about their role in maintaining terrestrial biodiversity, including primates. Madagascar's lemurs are a top global conservation priority, with $94 \%$ of species threatened with extinction, but records of their occurrence in mangroves are scarce. I used a mixed-methods approach to collect published and unpublished observations of lemurs in mangroves: I carried out a systematic literature search and supplemented this with a targeted information request to 1243 researchers, conservation and tourism professionals, and others who may have visited mangroves in Madagascar. I found references to, or observations of, at least 23 species in 5 families using mangroves, representing $>20 \%$ of lemur species and $>50 \%$ of species whose distributions include mangrove areas. Lemurs used mangroves for foraging, sleeping, and traveling between terrestrial forest patches, and some were observed as much as $3 \mathrm{~km}$ from the nearest permanently dry land. However, most records were anecdotal and thus tell us little about lemur ecology in this habitat. Mangroves are more widely used by lemurs than has previously been recognized and merit greater attention from primate researchers and conservationists in Madagascar.
\end{abstract}

Keywords Conservation · Madagascar $\cdot$ Primate-habitat interactions $\cdot$ Refuge Strepsirrhini

Electronic supplementary material The online version of this article (doi:10.1007/s10764-016-9905-1) contains supplementary material, which is available to authorized users.

Charlie J. Gardner

cg399@kent.ac.uk

1 Blue Ventures Conservation, 39-41 North Road, London N7 9DP, UK

2 Durrell Institute of Conservation and Ecology (DICE), School of Anthropology and Conservation, University of Kent, Canterbury, Kent CT2 7NR, UK 


\section{Introduction}

Mangroves are forests or other vegetated ecosystems that grow in the intertidal areas of subtropical and tropical coastlines around the world. They have attracted increasing conservation attention in recent years, in part as a result of an improved understanding of the ecosystem services they provide, which include carbon sequestration and storage (Donato et al. 2011; Nellemann et al. 2009; Pendleton et al. 2012; Ullman et al. 2012), as well as coastal protection and erosion prevention (Alongi 2008; Dahdouh-Guebas et al. 2005). In addition, mangroves provide breeding and feeding grounds for a range of marine species (Kathiresan and Bingham 2001; Nagelkerken et al. 2008), including fish and crustaceans that sustain major commercial fisheries (Manson et al. 2005; Naylor et al. 2000), and generate provisioning services for coastal human communities in many countries (Glaser 2003; Rasolofo 1997; van Bochove et al. 2014).

Despite the increased recognition of mangrove ecosystem services, our understanding of their importance for the maintenance of terrestrial biodiversity remains patchy (Nagelkerken et al. 2008), and this is the case even for charismatic vertebrates such as primates (Nowak 2012). Mangroves are marginal habitats for many terrestrial mammals owing to their extreme and dynamic conditions, including frequent inundation, low botanical and invertebrate diversity, and vegetation that tends to be unpalatable because of its high tannin content (Intachat et al. 2005; Kraus et al. 2003; Nagelkerken et al. 2008; Tomlinson 1995; Vannucci 2001). As a result, there are few obligate mangrove specialists, such as the proboscis monkey (Nasalis larvatus), among global primates, though at least 63 further species, including multiple species in the genera Procolobus, Cercopithecus, Macaca, and Presbytis, among others, are known to use this habitat facultatively (Nowak 2012): for many, mangroves may be used as a refuge following the loss or degradation of preferred terrestrial habitats. Given that mangroves are among the most threatened of all tropical ecosystems (Duke et al. 2007; Valiela et al. 2001) and have lost 20\%-35\% of their global extent since 1980 (FAO 2007; Polidoro et al. 2010; Valiela et al. 2001), an understanding of their role in maintaining primate populations is essential to inform conservation planning, as well as contributing to our knowledge and understanding of primate-habitat interactions.

Madagascar, a global conservation priority boasting unparalleled rates of diversity and endemism among its terrestrial fauna and flora (Brooks et al. 2006; Myers et al. 2000), is among the countries where mangrove use by terrestrial species is relatively poorly understood. With 213,000 ha of mangroves, Madagascar possesses ca. $2 \%$ of their global area and is among the top 15 mangrove-rich countries globally (FAO 2007; Giri 2011; Giri et al. 2011), yet research into use of the habitat by the country's reptile, bird, and mammal fauna remains in its infancy. Mangroves are distributed primarily along the west coast, with only small, localized patches in the east (Fig. 1): the greatest coverage is in the northwest, with the largest systems at Mahajamba Bay and AmbaroAmbanja Bays (Jones et al. 2015, 2016). The mangroves are species poor, containing only eight true mangrove species (Avicennia marina, Bruguiera gymnorrhiza, Ceriops tagal, Rhizophora mucronata, Sonneratia alba, Xylocarpus granatum, Lumnitzera racemosa, and Heritiera littoralis), and little is known about their importance for terrestrial biodiversity: the only group to have been surveyed in mangroves is birds, of which at least 99 species have been recorded (Gardner et al. unpublished data). Mangrove ecosystems provide a range of provisioning ecosystem services to adjacent human 


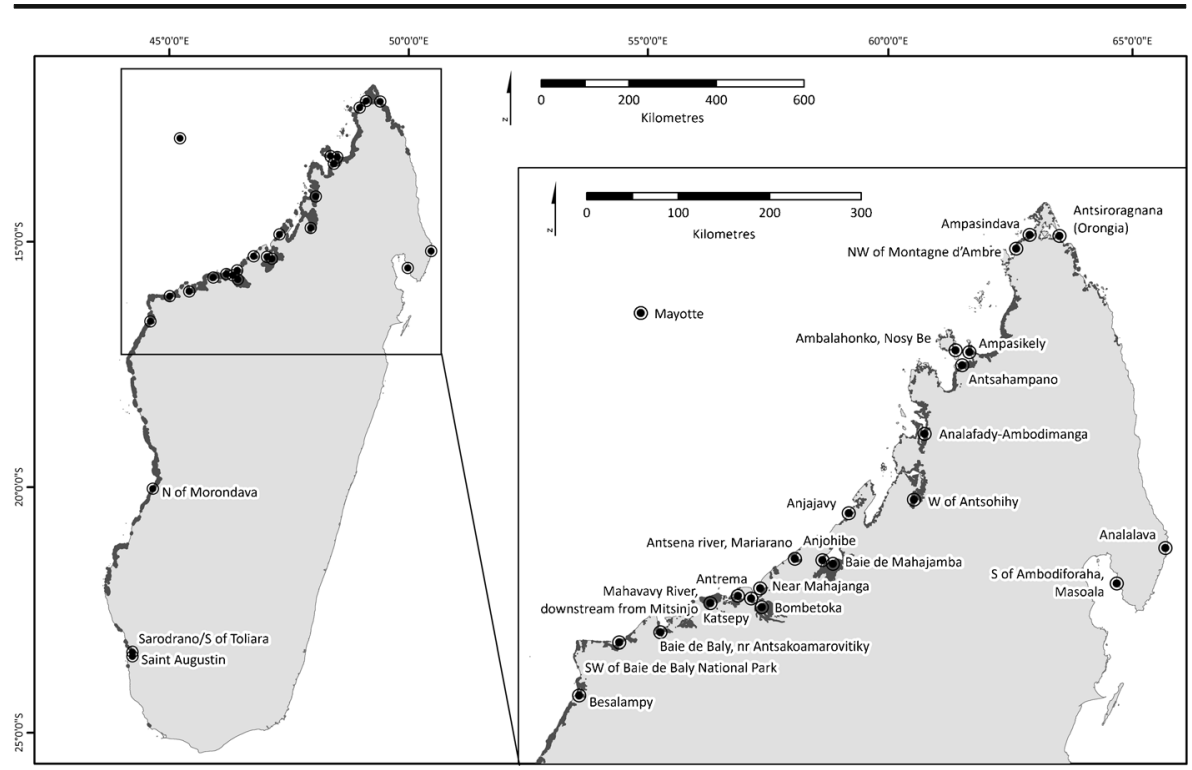

Fig. 1 Map of Madagascar showing the distribution of mangroves (dark gray, derived from Giri 2011) and 26 locations at which lemurs have been observed using mangrove habitats.

populations (Rasolofo 1997) and are thus heavily exploited throughout the country. Their management is hampered by a complex legal framework and they are poorly represented in the country's protected area system; as a result, their extent declined by 21\% between 1990 and 2010 (Jones et al. 2016).

Among the faunal groups that could be expected to use Madagascar's mangroves are primates, as Madagascar is among the richest countries for primate diversity, with 105 species, representing $>20 \%$ of global species-level and $30 \%$ of global family-level richness (Mittermeier et al. 2013). However, there remains no evidence of any mangrove specialist lemur species. Until recently our knowledge of mangrove use by lemurs consisted of a few scattered reports; however, two recent reviews have expanded our understanding considerably. Nowak (2012) found reference to four lemur species using mangroves, while Donati et al. (2016) collected reports concerning 12 species representing four of the five extant families. Here I expand on the work of these authors with the most thorough and systematic review yet conducted on mangrove use by lemurs. Although published observations of lemurs in mangroves are few, I hypothesized that lemurs may have been observed within this habitat by observers that enter mangroves for reasons other than primate research, and that any such observations may remain unpublished owing to their anecdotal nature. I therefore carried out a mixed-methods review designed to retrieve both published and unpublished reports.

\section{Methods}

To search for published observations, I carried out a systematic literature search for the terms lemur + mangrove and primate + mangrove in relevant online databases and search engines (Academic Search Complete, BioOne, Directory of Open Access 
Journals, Google Scholar, PrimateLit, Scopus, and Web of Science). I also searched for the term mangrove within the NOE 4D database of articles on natural history in Madagascar (comprising 2852 publications from the period 1658-2008), IUCN Red List web pages for all lemur species, and all volumes of Lemur News available in searchable PDF format (volumes 11-18, 2006-2014). To find unpublished observations, I compiled a database of 1243 individuals (including researchers, conservation nongovernmental organization staff, and tour operators and other tourism professionals) who may have spent time in or near mangroves in Madagascar, and sent them a targeted information request by email. Respondents were asked to fill out an online survey or a simple data sheet (both available in English and French; Electronic Supplementary Material) for any observations they had made, and to share the request within their professional networks. I also posted the information request on the Madagascar Environmental Justice Network, an online forum of $>1200$ members at the time of posting. I collated all the relevant information I retrieved in a database in Microsoft Excel ${ }^{\circledR}$, but did not perform further analyses because of the opportunistic, i.e., nonsystematic, nature of all observations.

Much of Madagascar's lemur diversity (particularly among nocturnal genera) is cryptic, preventing accurate field identifications to species level. I tentatively assign observations of such genera to species on the basis of known distributions from Mittermeier et al. (2010).

\section{Results}

I found references to, or observations of, mangrove use by at least 23 lemur species, representing all five extant lemur families (Cheirogaleidae 7, Lepilemuridae 3, Lemuridae 9, Indriidae 3, and Daubentoniidae 1) (Table I; Fig. 1). Of these, 11 species have not previously been reported as using mangrove habitats. The systematic literature search produced peer-reviewed records of mangrove use by two species (Eulemur fulvus and E. macaco) not reported in previous reviews, as well as a further record of one species (Lemur catta) already known to use this habitat. These records may have been previously overlooked because the word mangrove was not mentioned in the title, abstract, or keywords of the papers in question, and so may not have been picked up by search engines. The survey generated responses from 59 individuals including positive reports from 15 respondents relating to observations of 22 species; of these, at least 9 species have not previously been reported from mangrove habitats. Five records were supported by photographs (Fig. 2). Of the records that can be assigned to species on the basis of locality, 20 species are globally threatened with extinction, of which 3 are Vulnerable, 13 Endangered, and 4 Critically Endangered (Schwitzer et al. 2013). One additional species was reported by local staff of the Eden Reforestation Project and matches the description of Cheirogaleus medius, but I treat this record as unconfirmed because it was reported second hand and thus do not include it in the species totals.

Neither published records nor survey respondents tended to provide much information with regard to the behavior of observed lemurs within mangrove habitats, at least in part because observations were generally brief, one-off events, and the fact that it may be difficult to ascribe behavior categories to active individuals at night. Nevertheless, the reports indicate that different species may use mangroves for a variety 


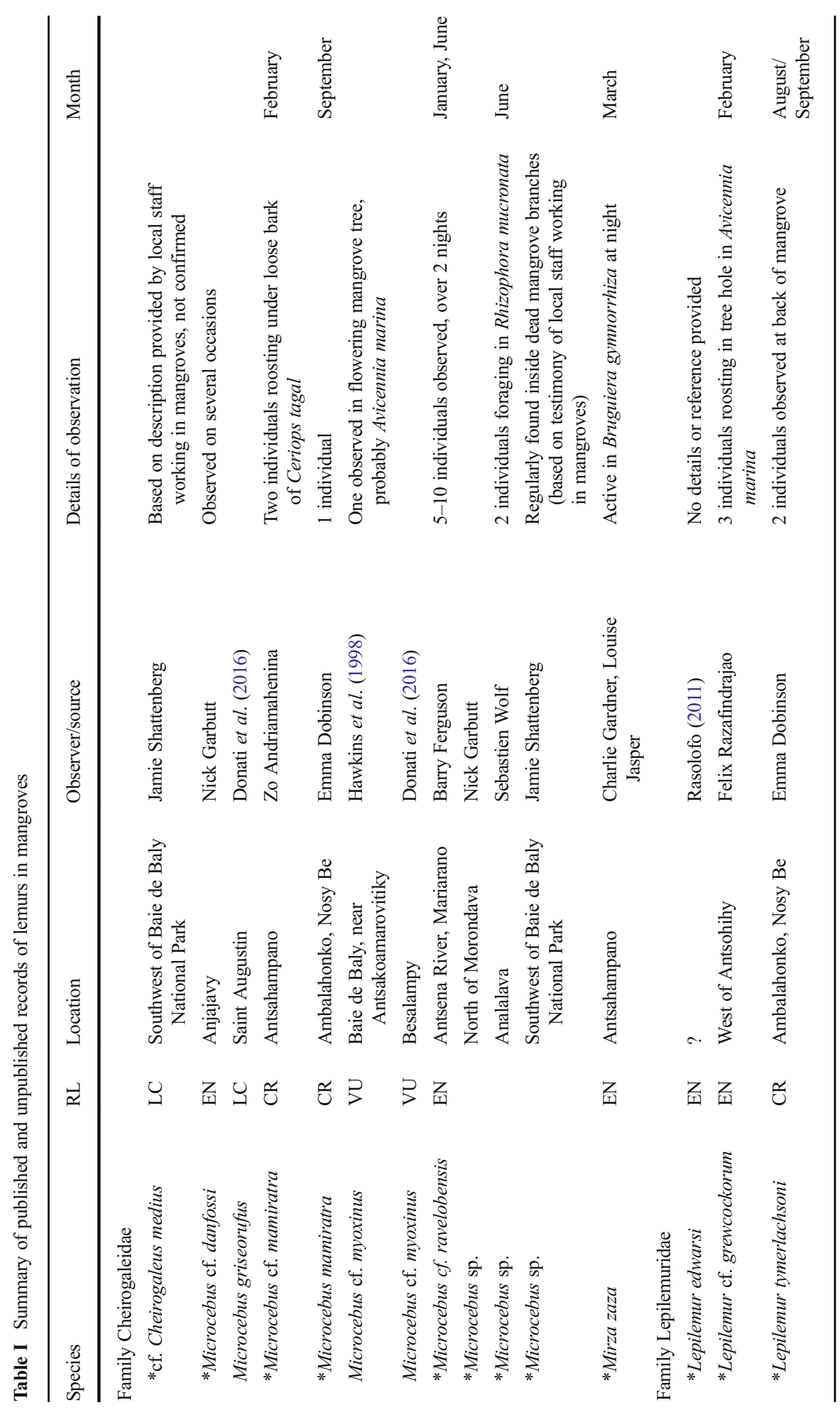




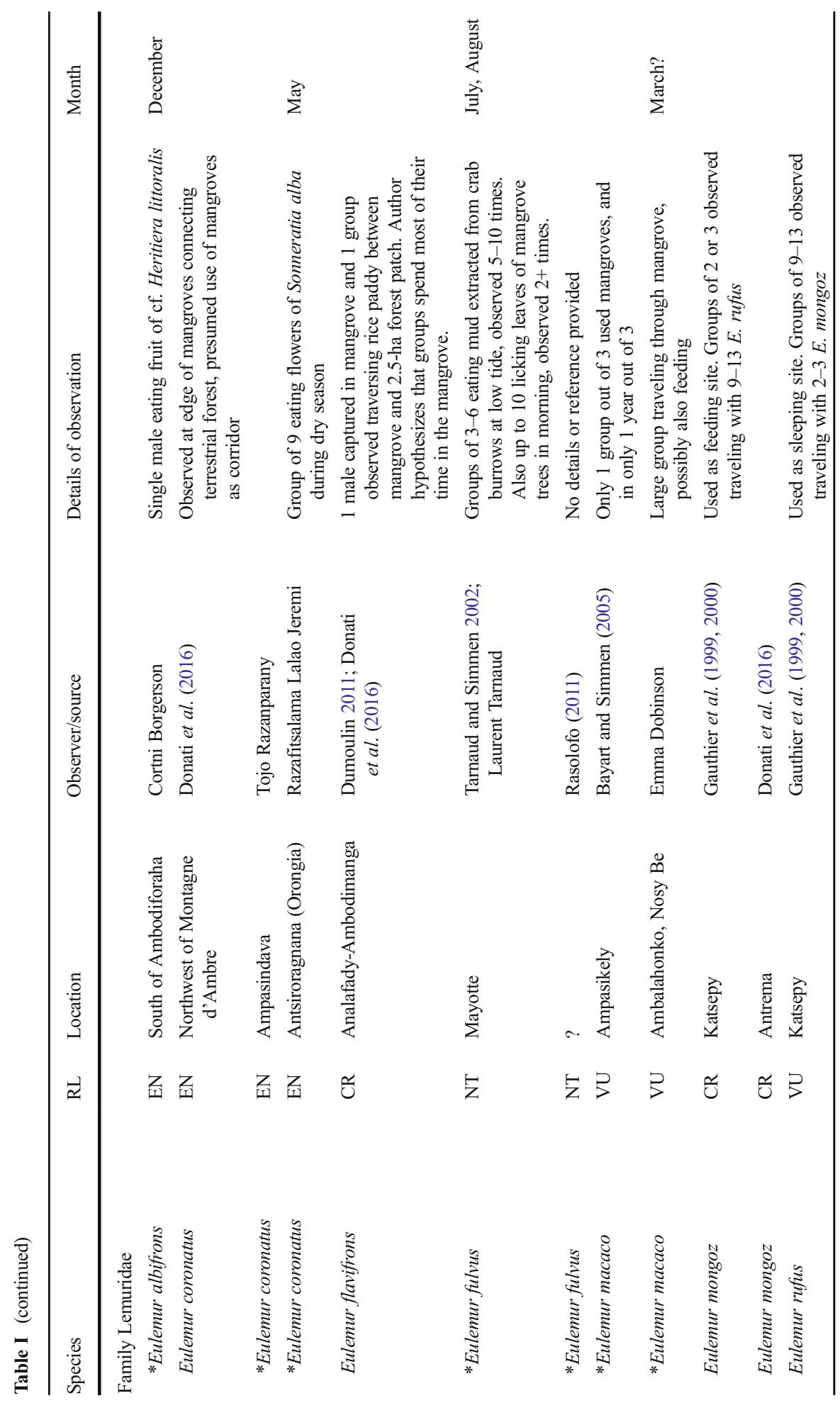















Fig. 2 Images of lemurs in mangroves provided by survey respondents. (a) Microcebus cf. mamiratra, disturbed from daytime sleeping site under loose bark of Ceriops tagal at Antsahampano (photo: Zo Andriamahenina). (b) Mirza zaza in Bruguiera gymnorrhiza at Antsahampano (photo: Louise Jasper). (c) Eulemur fulvus eating mud extracted from crab burrows in the mangrove at low tide, southern Mayotte (photo: Laurent Tarnaud). (d) Lepilemur cf. grewcockorum resting in tree hole in Avicennia marina, west of Antsohihy (photo: Felix Razafindrajao). (e) Group of Propithecus coronatus in dead mangrove tree at Antrema (photo: Laurent Tarnaud).

of reasons including shelter, moving between patches of terrestrial habitat, and procuring food or water. In terms of shelter, two nocturnal species, Microcebus cf. mamiratra and Lepilemur cf. grewcockorum, have been observed resting or sleeping in mangroves during the day, under the loose bark of Ceriops tagal and in a tree hole of Avicennia marina respectively (Z. Andriamahanina and F. Razafindrajao pers. comm.), while local staff of the Eden Reforestation Project "regularly" find Microcebus sp. and another, larger nocturnal species (probably Cheirogaleus medius) sleeping in holes and hollow branches of both living and dead mangrove trees, while they are collecting firewood in the mangroves (J. Shattenberg pers. comm.). The diurnal Eulemur rufus and Propithecus coronatus use mangroves as sleeping sites (Gauthier et al. 1999, 2000; L. Tarnaud and R. Ramanamisata pers. comm.), while Lemur catta shelters in the shade of mangroves during the heat of the day (Sauther et al. 2013; T. Mbohoahy pers. comm.). As well as resting and sleeping sites, mangroves may be used as corridors for travel between patches of terrestrial habitat, e.g., by Eulemur coronatus, E. sanfordi (Donati et al. 2016) and Propithecus coronatus (R. Ramanamisata pers. comm.).

In terms of foraging and food resources, C. Borgerson (pers. comm.) has observed Eulemur albifrons eating the fruit of cf. Heritiera littoralis, L. Razafitsalama (pers. comm.) has observed a group of nine E. coronatus eating the flowers of Sonneratia alba, and Lemur catta occasionally eats the leaves of Avicennia marina (T. Mbohoahy 
pers. comm., A. Randrianjohany pers. comm.). Mangroves have also been reported as a feeding site for Propithecus coronatus and Eulemur mongoz (Gauthier et al. 1999, 2000; R. Ramanamisata pers. comm.), though the species consumed were not specified. Among nocturnal species, S. Wolf (pers. comm.) has observed two individuals of Microcebus sp. in Rhizophora mucronata and Hawkins et al. (1998) observed Microcebus cf. myoxinus in a flowering Avicennia marina, although foraging was not directly observed in either case. B. Ferguson has observed 5-10 Microcebus cf. ravelobensis in mangroves at Mariarano over two nights; although he did not directly observe feeding behavior, the abundance of active mouse lemurs within this habitat suggests that the animals use it for foraging (B. Ferguson pers. comm.). On Mayotte (Comoros archipelago) the introduced Eulemur fulvus uses mangrove areas to seemingly supplement its diet with minerals; L. Tarnaud has watched groups of 3-6 eating mud extracted from crab burrows at low tide (observed 5-10 times), and up to 10 individuals licking the leaves of mangroves in the early morning (observed $2+$ times). In the latter instance, the observer believed that the lemurs may be licking dew as well as salt accreted from the leaves (L. Tarnaud pers. comm.). Finally, Lemur catta drinks water from freshwater seeps within mangroves in semi-arid areas of far southern Madagascar (Sauther et al. 2013; A. Randrianjohany pers. comm.).

Among observations for which spatially explicit data were provided $(N=21), 81 \%$ were of lemurs at the edge of the mangrove or $\leq 50 \mathrm{~m}$ of the nearest permanently dry land. Observations of Propithecus coquereli and Microcebus cf. ravelobensis at Mariarano ranged from $100 \mathrm{~m}$ to $1000 \mathrm{~m}$ from dry land (B. Ferguson pers. comm.), while Lepilemur cf. grewcockorum and Mirza zaza were observed at distances of ca. $2 \mathrm{~km}$ and $3 \mathrm{~km}$ from permanently dry land, respectively (F. Razafindrajao pers. comm.; C. Gardner and L. Jasper unpubl. data).

Few data are available on the seasonality of mangrove use, though reported observations show no clear patterns in temporal variation. Some species have been reported from mangroves at the same site in both wet and dry seasons, e.g., Microcebus cf. ravelobensis and Propithecus coquereli at Mariarano, and Propithecus coronatus at Katsepy, suggesting that mangrove use may be year-round for those species.

\section{Discussion}

Mangroves present a challenging environment for primates as a result of their frequent inundation, low botanical and structural diversity, and foliage that tends to be unpalatable because of a high tannin content (Kraus et al. 2003; Tomlinson 1995). They may also harbor lower invertebrate diversity and biomass than terrestrial forests, though comparative data are scarce (Intachat et al. 2005; Nagelkerken et al. 2008). Nevertheless this review has shown that diverse lemur species are able to use mangroves in some circumstances.

The published and unpublished observations collected here almost double the number of lemur species known to occur in mangroves and, alongside a recent review (Donati et al. 2016), increase the known number of global primate species using this habitat by almost 30\%, from 64 to 83 (Nowak 2012). They also add a new family (Lepilemuridae) and two new genera (Lepilemur, Mirza) to the global list. We now know that $>20 \%$ of lemur species venture into mangroves in at least part of their range, 
a high percentage given that about half of Madagascar's lemur species do not have distributions encompassing coastal areas, and almost $40 \%$ of species are restricted to eastern regions from which mangroves are largely absent. Based on a visual interpretation of distribution maps (Mittermeier et al. 2010), I estimate that 43 lemur species have known ranges likely to encompass mangrove areas, and 53\% of these species have now been recorded within them. These findings suggest that the facultative use of mangroves is much more widespread among lemurs than was previously thought, though there remains no evidence that any lemurs are obligate or specialist mangrove dwellers. The lack of specialist mangrove species may be considered surprising given that several lemur species (Hapalemur spp., Prolemur simus) are adapted to feeding on plants rich in unpalatable chemical components, e.g., bamboos (Poaceae: Glander et al. 1989; Yamashita et al. 2010), and one (Hapalemur alaotrensis) is restricted to aquatic vegetation in a freshwater wetland and may occasionally swim (Petter and Peyriéras 1975; Rendigs et al. 2015). Thus neither the unpalatability nor the regular inundation of mangroves need necessarily have constituted a barrier to the evolution of mangrove use by species in these genera.

Lemurs were reported to use mangroves for a variety of reasons, including 1) to rest or sleep in, 2) to rest in the shade during hot parts of the day, 3) to move between patches of forest, 4) to forage on mangrove tree resources (fruit, flowers, leaves), 5) to feed on minerals, and 6) to drink water. Some primarily insectivorous, nocturnal species, e.g. Microcebus spp., Mirza zaza, may also have been foraging nonvegetal resources, e.g. invertebrates, although foraging was only suspected by the observers and not confirmed. Mangroves may also provide a refuge from predation for some primate species owing to their regular inundation (Matsuda et al. 2010; Nowak 2012). Although evidence is lacking, this may also be a factor for some lemurs because nonavian lemur predators, which include Euplerid carnivores, domestic and feral cats and dogs, and a range of snakes (Gardner et al. 2015; Goodman 2003; Scheumann et al. 2007), are not known to occur in Madagascar's mangroves. Furthermore, mangroves may provide a refuge from human hunters, who target lemurs through much of Madagascar (Borgerson et al. 2016; Gardner and Davies 2014; Golden et al. 2014; Razafimanahaka et al. 2012).

The extent to which different species use mangroves varies greatly, and some species may occur in this habitat only occasionally or under rare circumstances. For example, Cortni Borgerson (pers. comm.) observed Eulemur albifrons in a mangrove only once, despite walking through that mangrove regularly over the course of multiple field seasons. Bayart and Simmen (2005) found only one of three focal groups of Eulemur macaco at Ampasikely to include mangroves within their territory, and only in one of three years, while Chris Birkinshaw (pers. comm.) studied this species in Nosy Be for 18 months without ever observing mangrove use, and villagers in Ankazomborona state that E. macaco does not enter mangroves even though it is common in adjacent degraded habitat (C. Gardner unpubl. data). Thus mangrove use may occur in some parts of a species' range but not in others.

For a small number of species mangrove use may be regular behavior, but even then only for a limited population within the species' ranges. For example, mangroves are said to be the preferred habitat of Propithecus coronatus at Antrema (Roger and Andrianasolo 2003), and were reported from there by four respondents in this study, while $P$. coquereli was reported to use mangroves at four different sites. However, most 
of these species' ranges lie away from coastal and estuarine areas, and at inland sites the animals are restricted to deciduous dry forests (Andriamasimanana and Cameron 2014; Kun-Rodrigues et al. 2014; Rakotonirina et al. 2013). Likewise mangrove use by Lemur catta has been widely reported from south of Toliara (Donati et al. 2016; Sauther et al. 2013; Scott et al. ND), though this may be the only area within the range of the species in which mangroves occur.

While most observations were made at or close to the edge of mangrove stands this is likely to reflect sampling bias, as their dense growth and regular inundation render mangroves much easier to travel past, on the landward or seaward side, than to travel through. Thus these data should not be regarded as evidence that lemurs tend only to use mangrove edge habitats. Indeed, observations of Microcebus cf. ravelobensis, Mirza zaza, and Lepilemur cf. grewcockorum at distances of $\geq 1 \mathrm{~km}$ from the nearest dry land demonstrate that these species penetrate deep into mangrove stands. Whereas the former were frequently observed in an area where mangroves are contiguous with intact native forest, the adjacent vegetation at Antsahampano where Microcebus cf. mamiratra and Mirza zaza were observed consisted of coconut plantations and nonnative scrub, while the landscape surrounding the mangrove in which Lepilemur cf. grewcockorum was observed is entirely deforested. The absence of contiguous native forest cover from these areas suggests that the observed populations are not dependent on source-sink dynamics and the immigration of individuals from areas of higher quality habitat (Pulliam 1988), but are in fact able to maintain viable populations in the mangrove. However, it should not be assumed that these populations will remain viable in the long term because there may be time lags associated with the impacts of landscape deforestation around mangroves, and the remaining lemur populations may thus be carrying an "extinction debt" (Hylander and Ehrlén 2013; Kuussaari et al. 2009). It has been hypothesized or demonstrated that lemurs and other primates may use mangroves as a refuge following loss of, or disturbance to, preferred habitats (Galat-Luong and Galat 2005; Gauthier et al. 2000; Nowak 2012). Although the presence of lemurs in mangroves lacking adjacent terrestrial habitats may be taken as evidence in support of this hypothesis, we cannot infer that mangroves are suboptimal habitat because we do not know whether these species also used mangroves when connecting terrestrial forests remained.

If mangroves do function as refuge habitats for some nocturnal lemurs, the key resource they provide may be daytime sleeping sites. Most species in the Cheirogaleidae and Lepilemuridae spend the day in nests or tree holes (Mittermeier et al. 2010), which provide shelter from predation and assist the maintenance of energysaving torpor (Dausmann et al. 2005; Ganzhorn and Schmid 1998). Respondents in this study reported several species in these families as sleeping within tree holes, under loose bark, and in hollow branches, often from areas lacking alternative sleeping sites, e.g., adjacent to deforested terrestrial landscapes. However, there is some indirect evidence that no lemurs widely use such mangrove refugia. The Madagascar teal (Anas bernieri) is a mangrove specialist duck that breeds only in tree holes in mature Avicennia marina (Young 2006; Young et al. 2013). Suitable nest sites are rare because Madagascar lacks hole-excavating animals such as woodpeckers; thus it has been hypothesized that the teal would not have been able to evolve its breeding habits if it had to compete for tree holes with lemurs (G. Young pers. comm.).

Much further research is required to understand better the role of mangroves in the maintenance of lemur populations. This is particularly important for a number of 
mangrove-using species in northwest Madagascar, such as Microcebus mamiratra, M. danfossi, Mirza zaza, and Lepilemur grewcockorum, which are classed as Endangered or Critically Endangered on the basis of their small range and declining area of occupancy (AOO). However, even if mangroves are demonstrated to provide important habitat for these species they may not be more secure than terrestrial forests, as mangrove deforestation rates may match or even exceed those of terrestrial forests in some parts of the region (Jones et al. 2014, 2015; ONE et al. 2013).

\section{Conclusions}

The mixed-methods approach I adopted for this review allowed the collection of numerous published and unpublished observations that together have greatly expanded our knowledge of mangrove use by lemurs. We now know that more than half of all lemurs with distributions encompassing mangrove areas are able to use them facultatively in some circumstances, and may do so for a number of reasons. However, observations are almost entirely anecdotal so our understanding of the role of mangroves in the maintenance of lemur populations remains extremely limited. Improving our knowledge will require systematic surveys of the country's remaining mangroves to understand better which species occur in them and where, as well as comparative focal studies of lemur populations in mangroves and adjacent terrestrial habitats to understand better the ecological role of mangroves in the maintenance of populations. Given the difficulties of surveying mangroves, camera trap and video technologies may provide useful tools in this regard. Ninety-four percent of all lemur species are threatened with extinction, primarily as a result of ongoing habitat loss (Schwitzer et al. 2013), and conservation efforts are focused overwhelmingly on Madagascar's terrestrial forests on which the vast majority of the country's lemurs depend. This review suggests that mangroves may provide important refuges and other resources for some species, and thus that Madagascar's mangroves merit increased attention from the country's primatologists and lemur conservationists.

Acknowledgments This research was carried out within the framework of a mangrove conservation project funded by the Global Environment Facility. I thank a large number of survey respondents for providing information; in addition to those listed in Table I these include Chris Birkinshaw, Giuseppe Donati, Joerg Ganzhorn, Colin Groves, Jacques Iltis, Chantal Misandeau, Ivan Norscia, Ian Tattersall, Glynn Young, and numerous others. I also thank Leah Glass for preparation of Fig. 1, and Zo Andriamahenina, Louise Jasper, Trevor Jones, and Kim Reuter for comments, information, and assistance. Two anonymous reviewers and the editor-in-chief also provided comments that greatly improved the clarity of the manuscript.

Open Access This article is distributed under the terms of the Creative Commons Attribution 4.0 International License (http://creativecommons.org/licenses/by/4.0/), which permits unrestricted use, distribution, and reproduction in any medium, provided you give appropriate credit to the original author(s) and the source, provide a link to the Creative Commons license, and indicate if changes were made.

\section{References}

Alongi, D. M. (2008). Mangrove forests: resilience, protection from tsunamis, and responses to global climate change. Estuarine, Coastal and Shelf Science, 76, 1-13.

Andriaholinirina, N., Baden, A., Blanco, M., Chikhi, L., Cooke, A., Davies, N., et al. (2014). Propithecus coquereli. The IUCN Red List of Threatened Species 2014: e.T18355A16115770. Accessed 4 Nov 2015. 
Andriamasimanana, R. H., \& Cameron, A. (2014). Spatio-temporal change in crowned (Propithecus coronatus) and Decken's sifaka (Propithecus deckenii) habitat in the Mahavavy-Kinkony Wetland Complex, Madagascar. Primate Conservation, 28, 65-71.

Bayart, F., \& Simmen, B. (2005). Demography, range use, and behaviour in black lemurs (Eulemur macaco macaco) at Ampasikely, Northwest Madagascar. American Journal of Primatology, 67, 299-312.

Borgerson, C., McKean, M. A., Sutherland, M. R., \& Godfrey, L. R. (2016). Who hunts lemurs and why they hunt them. Biological Conservation, 197, 124-130.

Brooks, T. M., Mittermeier, R. A., da Fonseca, G. A. B., Gerlach, J., Hoffmann, M., Lamoreux, J. F., et al. (2006). Global biodiversity conservation priorities. Science, 313, 58-61.

Dahdouh-Guebas, F., Jayatissa, L. P., di Nitto, D., Bosire, J. O., Lo Seen, D., \& Koedam, N. (2005). How effective were mangroves as a defence against the recent tsunami? Current Biology, 15, R443-R447.

Dausmann, K. H., Glos, J., Ganzhorn, J. U., \& Heldmaier, G. (2005). Hibernation in the tropics: lessons from a primate. Journal of Comparative Physiology B: Biochemical, Systems, and Environmental Physiology, $175,147-155$.

Decary, R. (1950). La faune malgache: Son rôle dans les croyances et les usages indigènes. Paris: Payot.

Donati, G., Eppley, T., Ralison, J., Youssouf, J., \& Ganzhorn, J. (2016). Living lemur lack: Why Madagascar has so few extant primates in flooded habitats. In A. A. Barnett, I. Matsuda, \& K. Nowak (Eds.), Primates in flooded habitats: Ecology and conservation. Cambridge: Cambridge University Press.

Donato, D. C., Kauffman, J. B., Murdiyarso, D., Kumianto, S., Stidham, M., \& Kanninen, M. (2011). Mangroves among the most carbon-rich forests in the tropics. Nature Geoscience, 4, 293-297.

Duke, N. C., Meynecke, J. O., Dittmann, S., Ellison, A. M., Anger, K., Berger, U., et al. (2007). A world without mangroves? Science, 317, 41-42.

Dumoulin, A. (2011). Etude morphométrique et génétique comparative de deux sous-espèces d'Eulemur macaco et d'une population de morphologie intermédiaire, dans le Parc National de Sahamalaza-Iles Radama, au nord ouest de Madagascar. PhD thesis, Ecole Nationale Veterinaire d'Alfort.

Food and Agricultural Organization (FAO). (2007). The world's mangroves 1980-2005. Rome: FAO.

Galat-Luong, A., \& Galat, G. (2005). Conservation and survival adaptations of Temminck's red colobus (Procolobus badius temmincki), in Senegal. International Journal of Primatology, 26, 585-603.

Ganzhorn, J. U., \& Schmid, J. (1998). Different population dynamics of Microcebus murinus in primary and secondary deciduous dry forests of Madagascar. International Journal of Primatology, 19, 785-796.

Gardner, C. J., \& Davies, Z. (2014). Rural bushmeat consumption within multiple-use protected areas: qualitative evidence from southwest Madagascar. Human Ecology, 42, 21-34.

Gardner, C. J., Radolalaina, P., Rajerison, M., \& Greene, H. W. (2015). Cooperative rescue and predator fatality involving a group-living strepsirrhine, Coquerel's sifaka (Propithecus coquereli) and a Madagascar ground boa (Acrantophis madagascariensis). Primates, 56, 127-129.

Gauthier, C. A., Deniaud, J. L., Leclerc-Cassan, M., Rakotomalala, M., Razafindramanana, S., \& Renson, G. (2000). Observations of lemurs in the mangroves of north-west Madagascar. Folia Primatologica, 71, 267.

Gauthier, C. A., Deniaud, J. L., Rakotomalala, M., Razafindramanana, S., \& Renson, G. (1999). Note sur la découverte d'un nouvel habitat occupé par les propithéques couronnés (Propithecus verreauxi coronatus) au nord-ouest de Madagascar. Primatologie, 2, 821-827.

Giri, C. (2011). National-level mangrove cover data-sets for 1990, 2000 and 2010. Sioux Falls: United States Geological Survey.

Giri, C., Ochieng, E., Tieszen, L. L., Zhu, Z., Singh, A., Loveland, T., et al. (2011). Status and distribution of mangrove forests of the world using earth observation satellite data. Global Ecology and Biogeography, 20, 154-159.

Glander, K. E., Wright, P. C., Seigler, D. S., Randrianasolo, V., \& Randrianasolo, B. (1989). Consumption of cyanogenic bamboo by a newly discovered species of bamboo lemur. American Journal of Primatology, 19, 119-124.

Glaser, M. (2003). Interrelations between mangrove ecosystem, local economy and social sustainability in Caeté Estuary, North Brazil. Wetlands Ecology and Management, 11, 265-272.

Golden, C. D., Bonds, M. H., Brashares, J. S., Rasolofoniaina, B. J. R., \& Kremen, C. (2014). Economic valuation of subsistence harvest of wildlife in Madagascar. Conservation Biology, 28, 234-243.

Goodman, S. M. (2003). Predation on lemurs. In S. M. Goodman \& J. P. Benstead (Eds.), Natural history of Madagascar (pp. 1221-1228). Chicago: University of Chicago Press. 
Hawkins, A. F. A., Durbin, J. C., \& Reid, D. B. (1998). The primates of the Baly Bay area, north-western Madagascar. Folia Primatologica, 69, 337-345.

Hylander, K., \& Ehrlén, J. (2013). The mechanisms causing extinction debts. Trends in Ecology and Evolution, 28, 341-346.

Intachat, J., Holloway, J. D., \& Speight, M. R. (2005). A preliminary assessment of the diversity of geometroid moths within different types of forests in Peninsular Malaysia. Malayan Nature Journal, 57, 1-28.

Jones, T. G., Glass, L., Gandhi, S., Ravaoarinorotsihoarana, L., Carro, A., Benson, L., et al. (2016). Madagascar's mangroves: quantifying nation-wide and ecosystem specific dynamics, and detailed contemporary mapping of distinct ecosystems. Remote Sensing, 8, 106.

Jones, T. G., Ratsimba, H. R., Ravaoarinorotsihoarana, L., Cripps, G., \& Bey, A. (2014). Ecological variability and carbon stock estimates of mangrove ecosystems in northwestern Madagascar. Forests, 5, 177-205.

Jones, T. G., Ratsimba, H. R., Ravaoarinorotsihoarana, L., Glass, L., Benson, L., Teoh, M., et al. (2015). The dynamics, ecological variability and estimated carbon socks of mangroves in Mahajamba Bay, Madagascar. Journal of Marine Science and Engineering, 3, 793-820.

Kathiresan, K., \& Bingham, B. (2001). Biology of mangroves and mangrove ecosystems. Advances in Marine Biology, 40, 81-251.

Kraus, T. E. C., Dahlgren, R. A., \& Zasoski, R. J. (2003). Tannins in nutrient dynamics of forest ecosystemsa review. Plant and Soil, 256, 41-66.

Kun-Rodrigues, C., Salmona, J., Besolo, A., Rasolondraibe, E., Rabarivola, C., Marques, T. A., et al. (2014). New density estimates of a threatened sifaka species (Propithecus coquereli) in Ankarafantsika National Park. American Journal of Primatology, 76, 515-528.

Kuussaari, M., Bommarco, R., Heikkinen, R. K., Helm, A., Krauss, J., Lindborg, R., et al. (2009). Extinction debt: a challenge for biodiversity conservation. Trends in Ecology and Evolution, 24, 564-571.

Manson, F. J., Loneragan, N. R., Skilleter, G. A., \& Phinn, S. R. (2005). An evaluation of the evidence for linkages between mangroves and fisheries: a synthesis of the literature and identification of research directions. Oceanography and Marine Biology, 43, 483-513.

Matsuda, I., Tuuga, A., \& Higashi, S. (2010). Effects of water level on sleeping-site selection and inter-group association in proboscis monkeys: why do they sleep alone inland on flooded days? Ecological Research, $25,475-482$.

Mittermeier, R. A., Louis, E. E., Jr., Richardson, M., Schwitzer, C., Langrand, O., Rylands, A. B., et al. (2010). Lemurs of Madagascar (3rd ed.). Arlington: Conservation International.

Mittermeier, R. A., Schwitzer, C., Johnson, S., \& Ratsimbazafy, J. (2013). Introduction. In C. Schwitzer, R. A. Mittermeier, N. Davies, S. Johnson, J. Ratsimbazafy, J. Razafindramanana, E. E. Louis Jr., \& S. Rjaobelina (Eds.), Lemurs of Madagascar: A strategy for their conservation 2013-2016 (pp. 5-11). Gland: IUCN.

Myers, N., Mittermeier, R. A., Mittermeier, C. G., da Fonseca, G. A. B., \& Kent, J. (2000). Biodiversity hotspots for conservation priorities. Nature, 403, 853-858.

Nagelkerken, I., Blaber, S. J., Bouillon, S., Green, P., Haywood, M., Kirton, L. G., et al. (2008). The habitat function of mangroves for terrestrial and marine fauna: a review. Aquatic Botany, 89, 155-185.

Naylor, R. L., Goldburg, R. J., Primavera, J. H., Kautsky, N., Beveridge, M. C. M., Clay, J., et al. (2000). Effect of aquaculture on world fish supplies. Nature, 405, 1017-1024.

Nellemann, C., Corcoran, E., Duarte, C. M., Valdés, L., de Young, C., Fonseca, L., et al. (2009). Blue carbon: The role of healthy oceans in binding carbon. Arendal: United Nations Environment Programme and GRID-Arendal.

Nowak, K. (2012). Mangrove and peat swamp forests: refuge habitats for primates and felids. Folia Primatologica, 83, 361-376.

ONE (Office National pour l'Environnement), DGF (Direction Générale des Forêts), FTM (FoibenTaosarintanin'i Madagascar), MNP (Madagascar National Parks), and Conservation International. (2013). Evolution de la couverture des forêts naturelles à Madagascar 2005-2010. Antananarivo: Office National pour l'Environnement.

Pendleton, L., Donato, D. C., Murray, B. C., Crooks, S., Jenkins, W. A., Sifleet, S., et al. (2012). Estimating global "blue carbon" emissions from conversion and degradation of vegetated coastal ecosystems. PLoS ONE, 7, e43542.

Petter, J.-J., \& Peyriéras, A. (1975). Preliminary notes on the behaviour and ecology of Hapalemur griseus. In I. Tattersall \& R. W. Sussman (Eds.), Lemur biology (pp. 281-286). New York: Plenum Press.

Polidoro, B. A., Carpenter, K. E., Collins, L., Duke, N. C., Ellison, A. M., et al. (2010). The loss of species: mangrove extinction risk and geographic areas of global concern. PLOS ONE, 5, e10095.

Pulliam, H. R. (1988). Sources, sinks and population regulation. American Naturalist, 132, 652-661. 
Rakotonirina, L. H. F., Randriatsara, F., Rakotoarisoa, A. H., Rakotondrabe, R., Razafindramanana, J., Ratsimbazafy, J., et al. (2013). A preliminary assessment of sifaka (Propithecus) distribution, chromatic variation and conservation in western central Madagascar. Primate Conservation, 28, 43-53.

Rasolofo, M. V. (1997). Use of mangroves by traditional fishermen in Madagascar. Mangroves and Salt Marshes, 1, 243-253.

Rasolofo, V. M. (2011). Etude écologique des ressources crevettières dans les mangroves de la Baie d'Ambaro (nord ouest de Madagascar); En vue d'une gestion durable de leur exploitation. $\mathrm{PhD}$ thesis, University of Antananarivo.

Razafimanahaka, J. H., Jenkins, R. K. B., Andriafidison, D., Randrianandrianina, F., Rakotomboavonjy, V., Keane, A., et al. (2012). Novel approach for quantifying illegal bushmeat consumption reveals high consumption of protected species in Madagascar. Oryx, 46, 584-592.

Rendigs, A., Reibelt, L. M., Ralainasolo, F. B., Ratsimbazafy, J. H., \& Waeber, P. O. (2015). Ten years into the marshes - Hapalemur alaotrensis conservation, one step forward and two steps back? Madagascar Conservation \& Development, 10, 13-20.

Roger, E., \& Andrianasolo, M. (2003). Mangroves and salt marshes. In S. M. Goodman \& J. Benstead (Eds.), Natural history of Madagascar (pp. 209-210). Chicago: University of Chicago Press.

Sauther, M. L., Cuozzo, F. P., Youssouf Jacky, I. A., Fish, K. D., LaFleur, M., Ravelohasindrazana, L. A. L., et al. (2013). Limestone cliff-face and cave use by wild ring-tailed lemurs (Lemur catta) in southwestern Madagascar. Madagascar Conservation \& Development, 8, 73-80.

Scheumann, M., Rabesandratana, A., \& Zimmermann, E. (2007). Predation, communication and cognition in lemurs. In S. L. Gursky \& K. A. I. Nekaris (Eds.), Primate anti-predator strategies (pp. 100-126). New York: Springer Science+Business Media.

Schwitzer, C., Mittermeier, R. A., Davies, N., Johnson, S., Ratsimbazafy, J., Razafindramanana, J., et al. (2013). Lemurs of Madagascar: A strategy for their conservation 2013-2016. Gland: IUCN.

Scott, D., Andriambolanoro, O. A., Mbohoahy, T., Raharinirina, N. L., Smith, M., Tanteliniaina, S., et al. (ND). University of Brighton spiny forest research expedition 2007/08: Final report. Brighton: University of Brighton.

Tarnaud, L., \& Simmen, B. (2002). A major increase in the population of brown lemurs on Mayotte since the decline reported in 1987. Oryx, 36, 297-300.

Tomlinson, P. B. (1995). The botany of mangroves. Cambridge: Cambridge University Press.

Ullman, R., Bilbao-Batista, V., \& Grimsditch, G. (2012). Including blue carbon in climate market mechanisms. Ocean and Coastal Management, 83, 15-18.

Valiela, I., Bowen, J. L., \& York, J. K. (2001). Mangrove forests: one of the world's threatened major tropical environments. Bioscience, 51, 807-815.

van Bochove, J., Sullivan, E., \& Nakamura, T. (Eds.). (2014). The importance of mangroves to people: A call to action. Cambridge: United Nations Environment Programme-World Conservation Monitoring Centre.

Vannucci, M. (2001). What is so special about mangroves? Brazilian Journal of Biology, 61, 599-603.

Yamashita, N., Tan, C., Vinyard, C. J., \& Williams, C. (2010). Semi-quantitative tests of cyanide in foods and excreta of three Hapalemur species in Madagascar. American Journal of Primatology, 72, 51-61.

Young, H. G. (2006). Madagascar teal Anas bernieri: The ecology and conservation of a short distance migrant. In G. C. Boere, C. A. Galbraith, \& D. A. Stroud (Eds.), Waterbirds around the world (pp. 252254). Edinburgh: The Stationery Office.

Young, H. G., Razafindrajao, F., Bin Aboudou, A. I., Woolaver, L. G., \& Lewis, R. E. (2013). Madagascar teal Anas bernieri: A mangrove specialist from Madagascar's west coast. In G. Gleason \& T. R. Victor (Eds.), Mangrove ecosystems: Biogeography, genetic diversity and conservation strategies (pp. 157-166). New York: Nova Publishers. 